\title{
A new Fridericia species (Clitellata, Enchytraeidae) and the enchytraeid fauna of the Őrség National Park (Hungary)
}

\author{
K. DÓZSA-FARKAS ${ }^{1} \&$ T. FELFÖLDI ${ }^{2}$ \\ ${ }^{1}$ Klára Dózsa-Farkas, Department of Systematic Zoology and Ecology, Eötvös Loránd University, \\ H-1117 Budapest,Pázmány Péter sétány1/C,Hungary.E-mail:kdozsafarkas@gmail.com \\ ${ }^{2}$ Tamás Felföldi, Department of Microbiology, Eötvös Loránd University, H-1117 Budapest, \\ Pázmány Péter sétány 1/C, Hungary. E-mail: tamas.felfoldi@gmail.com
}

\begin{abstract}
The enchytraeid fauna of the Örség National Park (Western Hungary), hitherto unknown, was investigated in this study. 14 enchytraeid genera including 47 species and one other annelid worm (Hrabeiella periglandulata) were identified. One enchytraeid species was found to be new to science and is described in this paper as Fridericia zicsii sp. nov. The new species is distinguishable based on both morphological characters and molecular data (mitochondrial cytochrome c oxidase subunit I, nuclear histone 3 genes and nuclear ribosomal ITS region sequences) from similar species. The enchytraeid fauna of Örség NP indicated well the subalpine nature of this area. The most species-rich site was the hay meadow (32 species) and interestingly, the species number in the Sphagnum bog of Szöce was unusually high (19 species).
\end{abstract}

Keywords. Fridericia, new species, Enchytraeidae, fauna, Örség National Park

\section{INTRODUCTION}

A $\mathrm{n}$ intensive investigation of the Hungarian enchytraeid fauna was launched in 2001 with support from the Hungarian Scientific Research Fund (OTKA), and so far resulted in publication of three comprehensive works on the enchytraeid fauna of Hungary. First, the enchytraeid fauna of the Northern Hungarian Mountains (Bükk, Mátra, Zemplén, Börzsöny Mts.) was investigated resulting in recording of 77 species belonging to 14 genera including five species new to science (Marionina sexdiverticulata Dózsa-Farkas, 2002, Achaeta unibulba Graefe, Dózsa-Farkas \& Christensen, 2005, Fridericia eiseni Dózsa-Farkas, 2005, F. schmelzi Cech \& Dózsa-Farkas, 2005 and $F$. crassiductata Dózsa-Farkas \& Cech, 2006 (Dózsa-Farkas 2002, Dózsa-Farkas 2005, Cech \& Dózsa-Farkas 2005, Graefe, Dózsa-Farkas \& Christensen 2005, Dózsa-Farkas \& Cech 2006, Dózsa-Farkas 2007). Between 2005-2009 the fauna of the Verrtes Mts. (belonging to the Transdanubian Mountains) was investigated. From this area 41 species and one subspecies distributed in 11 genera were identified including a new species and also a new subspecies (Fridericia mahunkai and Fridericia gamotheca hungarica) (DózsaFarkas 2013). As third region, the exploration of the Danube-Dráva National Park was carried out in 2011-2014 and a total of 14 enchytraeid genera including 49 species and two other annelid worms were identified of which four species were new to science (Fridericia connatiformis, $F$. phaeostriata, F. longiducta. and Cernosvitoviella buekkhati) (Dózsa-Farkas et al. 2015).

Within the last project in 2014 and 2015, the Örség National Park was investigated and the faunistic results of this study and description of a new species Fridericia zicsii sp. nov. are herewith presented. The morphological studies were supplemented with molecular-taxonomic analyses targeting the nuclear ribosomal ITS region, the mitochondrial cytochrome c oxidase subunit I (COI) gene and the nuclear histone $3(\mathrm{H} 3)$ gene.

urn: lsid:zoobank.org:pub:EDAF350E-4A5D-4B0C-8F09-2D5E930064D0

HU ISSN 2063-1588 (online), HU ISSN 0237-5419 (print) http://dx.doi.org/10.18348/opzool.2016.1.65 


\section{MATERIAL AND METHODS}

Study area. The Örség National Park is situated in Western Hungary $\left(46^{\circ} 51^{\prime}-55^{\prime} \mathrm{N}, 16^{\circ} 06^{\prime}-\right.$ $\left.24^{\prime} \mathrm{E}\right)$. The yearly average precipitation is 700 $800 \mathrm{~mm}$, the mean annual temperature is 9.0 $9.5{ }^{\circ} \mathrm{C}$. The elevation range of the area is approximately $250-350 \mathrm{~m}$ above sea level, and the landscape is divided into hills and valleys (Dövényi 2010). The bedrock consists of alluvial gravel and loess, the most frequent soil types are pseudogleyic and lessivaged brown forest soils, which are nutrient poor. The $\mathrm{pH}$ of the soil is acidic, ranging from 4.0 to 4.8 (mean 4.3) (Juhász et al. 2011). Forests cover an area of ca. $350 \mathrm{~km}^{2}$, which represents $80 \%$ of the Örség NP. Stands are dominated by Fagus sylvatica, Quercus petraea, Q. robur, Carpinus betulus, Pinus sylvestris and Picea abies. Mixed stands with great compositional diversity are frequent, but some are dominated by a single tree species. The most frequent non-dominant tree species are Betula pendula, Populus tremula, Castanea sativa, Prunus avium, Tilia spp., and Acer spp. Most of the original forests of the region were cut in the middle ages and in the regrown secondary forest the proportion of pioneer tree species (such as Pinus sylvestris and Betula pendula) and the cover of acidofrequent herbs, bryophytes and lichens increased (Gyöngyössy 2008, Tímár et al. 2002).

Collection sites. In total, 16 macro- and microhabitats were sampled at 9 localities (Appendix $1)$.

Morphological methods. The animals were extracted from the soil by the wet funnel method (O'Connor 1962). Worms were first studied and measured alive, and subsequently preserved in $70 \%$ ethanol. Later, a part of the adult F. zicsii specimens was stained with borax-carmine, then passed through an ethanol ( $70 \%$ to absolute) dehydration series, mounted temporarily in clove oil, and later mounted in Euparal in a slide between two coverslips. The important morphological structures were recorded in vivo, drawn, and photographed using an Axio Imager.A2 microscope with DIC (differential interference contrast) il- lumination and an AxioCam MRc 5 (Zeiss) digital camera with Axiovision software. The wholemounted specimens were reinvestigated and also photographed. Holotype and paratypes of the new species are deposited in the collection of the Department of Systematic Zoology and Ecology, Eötvös Loránd University (Budapest, Hungary).

Methods of molecular analysis. From the individuals subjected to molecular taxonomic analysis, genomic DNA was extracted with the DNeasy Blood \& Tissue Kit (Qiagen) following the instructions given by the manufacturer. The mitochondrial cytochrome c oxidase subunit I (CO1) gene, the nuclear histon 3 (H3) gene and the nuclear ribosomal ITS region were amplified using the primers $\mathrm{HCO} 2198$ (5'-TAA ACT TCA GGG TGA CCA AAA AAT CA-3') and LCO1490 (5'-GGT CAA CAA ATC ATA AAG ATA TTG G-3') (Folmer et al. 1994), H3a-F (5'ATG GCT CGT ACC AAG CAG ACV GC-3') and H3a-R (5'-ATA TCC TTR GGC ATR ATR GTG AC-3') (Colgan et al. 1998), and ETTS1 (5'TGC TTA AGT TCA GCG GGT-3') and ETTS2 (5'-TAA CAA GGT TTC CGT AGG TGA A-3') (Kane \& Rollinson 1994), respectively. PCRs were performed applying the parameters given by Dózsa-Farkas \& Felföldi (2015). Purification and sequencing of PCR products were carried out by LGC Genomics GmbH (Berlin, Germany). Removal of primer sequences and manual correction of automatic base calling on chromatograms were performed using the Chromas software v. 1.45 (Technelysium). Phylogenetic analyses (which included the search for the best-fit models) were conducted with the MEGA 6.0 software (Tamura et al. 2013). Sequences determined in this study were deposited in GenBank under the following accession numbers: KU586612-KU586627 (ITS), KU586582-KU586595 (CO1) and KU586596KU586611 (H3).

\section{RESULTS}

\section{Results of morphological analysis}

In total 47 species were recorded belonging to 14 enchytraeid genera, moreover a terrestrial po- 
lychaete, Hrabeiella periglandulata, was also collected (Appendix 2). All species represent new records for the Örség National Park. The status of one Fridericia species (Fridericia sp. 1) has not been ascertained yet. This probably also represents a new species for science, but further investigations are needed to clarify its status. A list of species recorded in individual samples, representing microhabitats sampled at the individual sites, is given in Appendix 2.

\section{DESCRIPTION OF THE NEW SPECIES}

\section{Fridericia zicsii sp. nov.}

(Figures 1-5)

Material examined. Holotype. F.25 slide No. 2078, adult, stained whole mounted specimen. Type locality. Örség, Gödörházi rétek (specially protected area) on the edge of alder carr with $\mathrm{He}$ merocallis lilio-asphodelus. $46^{\circ} 44.782 \mathrm{~N} \quad 16^{\circ}$ 21.227E, $229 \mathrm{~m}$ a.s.1., leg. K. Dózsa-Farkas, J. Farkas, Z. Tóth \& F. Hoc, 31.03.2014 (site 3b in Table 1). Paratypes (in total, 30 specimens). P.108.1.1-6 slide No. 1007-1009, 1066-1067, 2077. Six specimens from type locality, leg. K. Dózsa-Farkas, J. Farkas, Z. Tóth \& F. Hoc, 31.03.2014. P.108.2.1-3 slide No. 2059-2060, 2076. Three specimens from Gödörházi rétek, hay medow with Salix rosmarinifolia, $46^{\circ} 44.931 \mathrm{~N}$ $16^{\circ} 21.177 \mathrm{E}, 229 \mathrm{~m}$ a.s.l., leg. K. Dózsa-Farkas, J. Farkas, Z. Tóth \& F. Hoc, 31.03.2014. P.108.3.14 slide No. 2103-2106. Four specimens from Gödörházi rétek, hay medow with Salix rosmarinifolia, $46^{\circ} 44.931 \mathrm{~N} 16^{\circ} 21.177 \mathrm{E}, 229 \mathrm{~m}$ a.s.l., leg. Z. Tóth, 09.11.2014. P.108.4.1. Four specimens in ethanol from type locality, leg. K. DózsaFarkas, J. Farkas, Z. Tóth \& F. Hoc, 31.03.2014. P.108.4.2. Ten specimens in ethanol Örség, Gödörházi rétek, hay medow with Salix rosmarinifolia, $46^{\circ} 44.931 \mathrm{~N} 16^{\circ} 21.177 \mathrm{E}, 229 \mathrm{~m}$ a.s.l., leg. Z. Tóth, 09.11.2014. P.108.4.3. Three specimens in ethanol from Örség, Gödörházi rétek, hay medow with Salix rosmarinifolia, $46^{\circ} 44.931 \mathrm{~N} \quad 16^{\circ}$ 21.177E, 229 m a.s.1., leg. Z. Tóth, 26.10.2015.

Further material examined. 16 specimens from both localities (sites $3 \mathrm{~b}$ and 4 in Table 1).
Diagnosis. The new species can be recognized by the following combination of characters: (1) large size (14-20 mm long and about 400 wide in vivo), but the cuticle thin (maximum $1.5 \mu \mathrm{m}$ ), segments $48-65$; (2) maximum 4-5 chaetae per bundle; (3) clitellum girdle-shaped, gland cells arranged in transverse, dense rows, gland cells absent between the bursal slits but area glareosa developed instead; (4) five preclitellar pairs of nephridia; (5) dorsal blood vessel originating in XVII-XX, blood light pink; (6) coelomo-mucocytes with hyaline globulose matrix, lenticytes scarce; (7) chylus cells in XII-XIV (2 segments); (8) seminal vesicle large; (9) subneural glands absent; (10) sperm funnel cylindrical, about the same length or $2 / 3$ as long as body diameter; (11) spermathecae with short ectal duct, with 2 (3) very large ectal glands, the spherical ampulla with two oval or bean-shaped, large diverticula (diameter 60-90 $\mu \mathrm{m}$ in vivo), separate openings into oesophagus.

Description. Large species, holotype $17.5 \mathrm{~mm}$ long, $420 \mu \mathrm{m}$ wide at VIII and $550 \mu \mathrm{m}$ at clitellum in vivo, $11.8 \mathrm{~mm}$ long, $490 \mu \mathrm{m}$ wide at VIII and $570 \mu \mathrm{m}$ at clitellum (fixed), segments 59 . Body length of paratypes 14-20 mm, width 350$450 \mu \mathrm{m}$ at VIII and 370-580 $\mu \mathrm{m}$ at clitellum in vivo, length of fixed specimens $8-13 \mathrm{~mm}$, width $360-500 \mu \mathrm{m}$ at VIII and $450-590 \mu \mathrm{m}$ at clitellum, segments 48-65. Chaetal formula: 3,4-4,3,(1),2 : $3, \underline{4,5-4,3,2}$. The chaetae within a bundle arranged in pairs with the outer being longer and thicker than the inner $(40-50 \times 5 \mu \mathrm{m} v s .45-35 \times 4 \mu \mathrm{m}$, in preclitellar ventral bundles), the length of the chaetae in the lateral bundles somewhat longer (54 and $40 \mu \mathrm{m}$, respectively). Chaetal lengths about the same in postclitellar segments. From about XXV-XXXII, only two chaetae per bundle, these $60-70 \mu \mathrm{m}$ long in terminal segments. Head pore a longitudinal slit at $0 / \mathrm{I}$ (Fig. 2A). Dorsal vessel from XVII-XX, blood light pink (Fig. 2D). Epidermal gland cells inconspicuous. Clitellum in XII-1/3XIII, girdle-shaped, hyalocytes and granulocytes arranged in dense rows dorsally (Fig. 2F), sometimes irregularly, around the male copulatory organs only granulocytes (Fig. 2E), but between the bursal slits the glandular cells absent (Fig. 2H) 


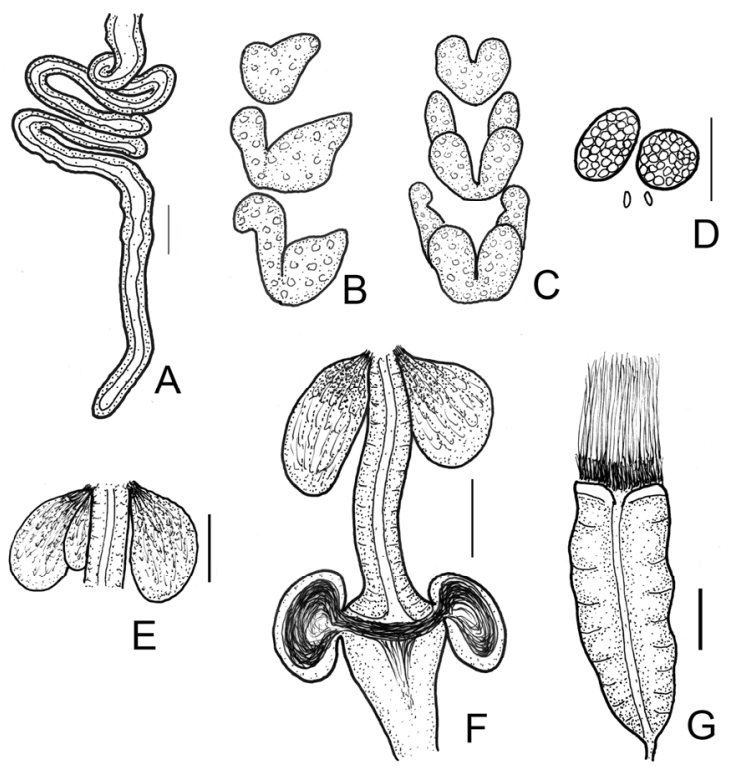

Figure 1. Fridericia zicsii sp. nov. A = oesophageal appendage, $\mathrm{B}=$ pharyngeal glands in lateral view (schematic), $\mathrm{C}=$ pharyngeal glands in dorsal view (schematic), $\mathrm{D}=$ coelomocytes, $\mathrm{E}=$ three ectal glands of spermathaeca, $\mathrm{F}=$ spermatheca, $\mathrm{G}=$ sperm funnel; scale bars $=50 \mu \mathrm{m}($ except $\mathrm{G}=100 \mu \mathrm{m})$.

while here an area glareosa well developed (Fig. $2 \mathrm{G})$. Body wall about $25-40 \mu \mathrm{m}$ thick, cuticula thin, $1-1.5 \mu \mathrm{m}$ in vivo.

Brain (Fig. 2B, C) about $200 \mu \mathrm{m}$ long and 1.8 times longer than wide in vivo, anterior and posterior margin with slight convexity. Oesophageal appendages (Fig. 1A) long, coiled, unbranched, type $\mathrm{b}$ (rarely two short branches at the end). All pairs of pharyngeal glands united dorsally and with ventral lobes in V and VI (Fig. 1B, C). Chloragocytes from $\mathrm{V}, 23-26 \mu \mathrm{m}$ long, brown in vivo. Midgut pars tumida in XXX-XLIV (in 710 segments) [but in two specimens in $\mathrm{XXV}-$ XXXI (8 segments)] the height of cells $63-65 \mu \mathrm{m}$ (Fig. 3A-B). Five pairs of preclitellar nephridia from $6 / 7$ to $10 / 11$; length ratio anteseptale : postseptale about $1: 1.5$, medial origin of efferent duct (Fig. 3H). Coelomo-mucocytes with characteristic hyaline globulose matrix (Fig. 1D, 3C-E), but in aggregations dark grey, length mostly 30 $45 \mu \mathrm{m}$, lenticytes scarce, $7-10 \mu \mathrm{m}$ long, in vivo. Chylus cells (Fig. 3F-G) between XII-XIV, occupying 2 segments. Seminal vesicle large (XXI). Sperm funnels cylindrical (Figs. 1G, 4A-B), $320-500 \mu \mathrm{m}$ long in vivo, 2.5-4 times longer than

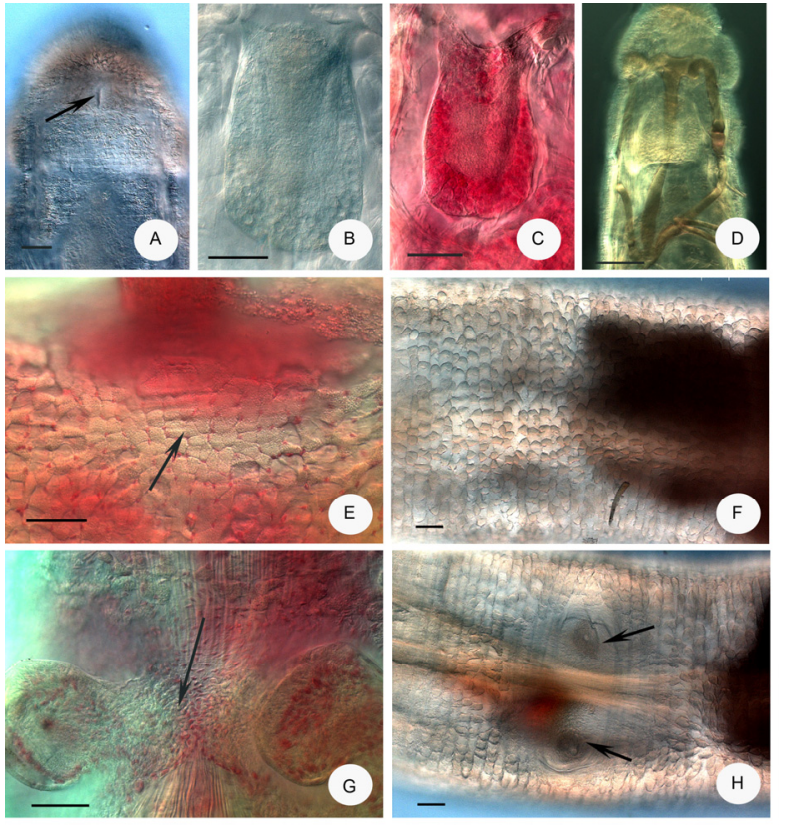

Figure 2. Micrograph of Fridericia zicsii sp. nov. A = headpore (marked with arrow), $\mathrm{B}-\mathrm{C}=$ brain, $\mathrm{D}=$ dorsal blood vessel anteriorly (blood pink), $\mathrm{E}=$ clitellar gland cells near to the male copulatory organ, lateraly only granulocytes (marked with arrow), $\mathrm{F}=$ clitellar gland cells dorsally (hyalocytes and granulocytes in dense transverse rows), $\mathrm{G}=$ between the two bursal slits the glands absent, but area glareosa well developed (marked with arrow), $\mathrm{H}=$ clitellum in ventral view (the two male copulatory organs are marked with arrws). A, B, D, F, H in vivo, C, E, G fixed, stained; scale bars $=50 \mu \mathrm{m}$.

wide, but in fixed specimens the length of funnels 230-330 $\mu \mathrm{m}$, and about 1.5-3 times longer than wide. Collar slightly narrower than funnel body. Length of spermatozoa $190-250 \mu \mathrm{m}$, heads $60-80$ $\mu \mathrm{m}$, in vivo. Diameter of sperm ducts about 10 $\mu \mathrm{m}$, in vivo. Male copulatory organs large (Fig. $4 \mathrm{C}-\mathrm{D}), 250-300 \mu \mathrm{m}$ long, $140-160 \mu \mathrm{m}$ wide and $110-130 \mu \mathrm{m}$ high, in vivo $(200-285,120-160$ and 95-130 $\mu \mathrm{m}$, fixed, respectively), the modiolus and area glareosa well developed, and covering the medial surface of the bursa (Fig. 4C). The bursal slits are T-shaped (Fig. 4E). No subneural glands. Ectal ducts of spermathecae short, length 180-260 $\mu \mathrm{m}$ and width $26-30 \mu \mathrm{m}(130-170 \mu \mathrm{m}$ long and 25-28 $\mu \mathrm{m}$ wide, fixed), the canal of duct 5-6 $\mu \mathrm{m}$ wide in vivo. Two very large brownish glands at the ectal openings of the spermathecal ducts (but in size different, $80-160 \mu \mathrm{m}$ long in vivo and fixed alike). Rarely, there is a third smaller gland 


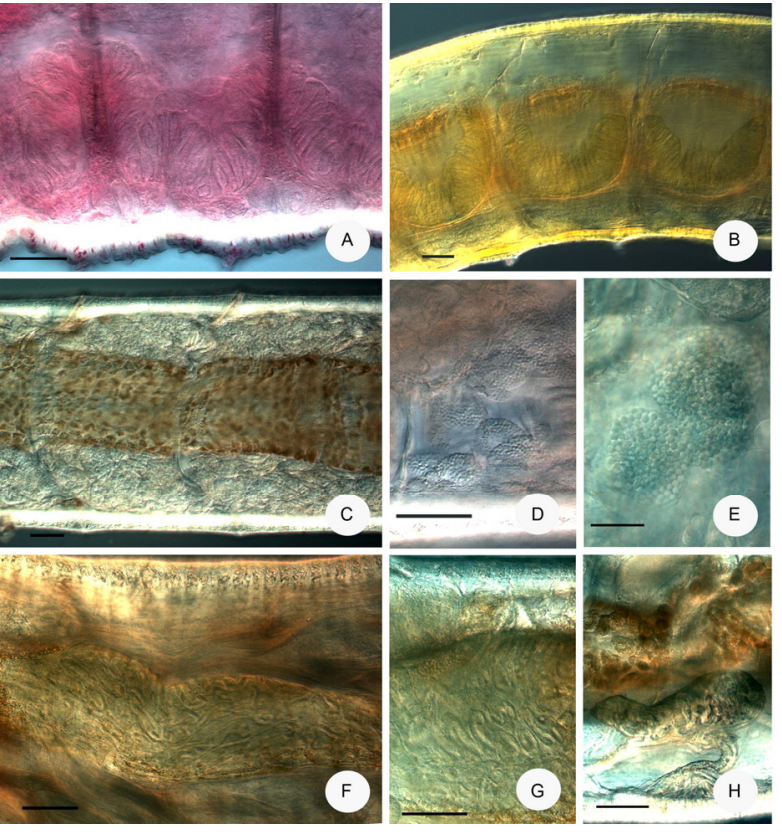

Figure 3. Micrograph of Fridericia zicsii sp. nov. $\mathrm{A}=$ pars tumida in XXVI-XXVII (fixed and stained), B = pars tumida in XXXVI-XXXVIII (fixed but not stained), C-E coelomocytes, $\mathrm{F}-\mathrm{G}=$ chylus cells in $\mathrm{XIII}-\mathrm{XIV}, \mathrm{H}=$ second antecli-

tellar nephridium. $\mathrm{C}-\mathrm{H}$ in vivo; scale bars $=50 \mu \mathrm{m}$ (except $\mathrm{E}=20 \mu \mathrm{m})$

(Fig. 1E-F, 4F, 5A-C). The glands consist of a complex of many gland cells, which open one by one to the surface (Fig. 5F). Ampullae onionshaped, diameter 75-85 $\mu \mathrm{m}$ in vivo (fixed 50-80 $\mu \mathrm{m})$, with two sessile oval, bean-shaped or rounded thin-walled diverticula about 70-90 $\mu \mathrm{m}$ long and $60-70 \mu \mathrm{m}$ wide when fixed, mostly filled with sperm (Fig1F, 4A-C). In one case, three diverticula were present in one of the two spermathecae (Fig. 5E). The ectal duct projecting into the lumina of ampullae, ental bulbs $40-50 \mu \mathrm{m}$ wide, fixed (Figs. 5B). Distal and proximal parts of ampullae mostly not set off by a constriction, separate openings into oesophagus. One to four mature eggs at a time.

Distribution and habitat. Only in the specially protected area Gödörházi rétek of Örség National Park: on the edge of alder carr with Hemerocallis lilio-asphodelus and a hay medow with Salix rosmarinifolia.

Etymology. Named in honour of my late colleague, the excellent earthworm taxonomist, Prof. Dr. András Zicsi.

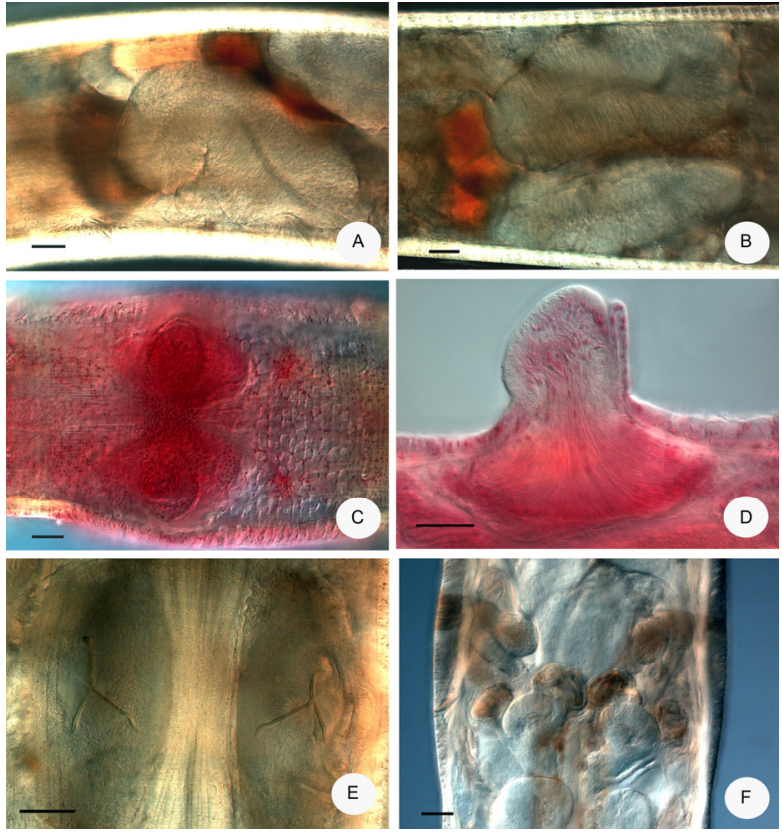

Figure 4. Micrograph of Fridericia zicsii sp. nov. A-B = sperm funnels, $\mathrm{C}=$ male copulatory organs and the clitellar region ventrally, $\mathrm{D}=$ bursa everted, $\mathrm{E}=$ bursal slits, $\mathrm{F}=$ the two spermathaecae. A, B, E, F in vivo, C-D stained; scale bars $=50 \mu \mathrm{m}$.

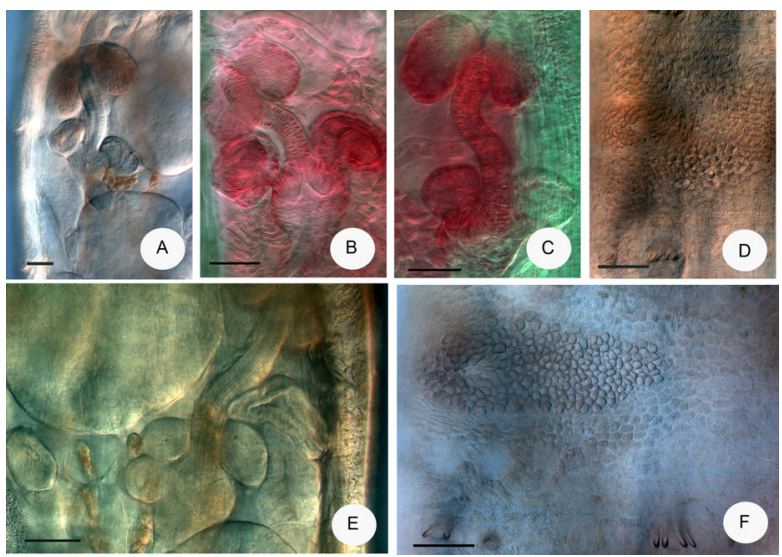

Figure 5. Micrograph of Fridericia zicsii sp. nov. A-C = spermathecae with two diverticula and large ectal glands, $\mathrm{E}=$ spermatheca exceptionally with three diverticula, D, F = gland openings of the complex spermathecal ectal glands. A, D, E,

$\mathrm{F}$ in vivo, B-C fixed, stained; scale bars $=50 \mu \mathrm{m}$.

Remarks. Among the previously described Fridericia species with oval or bean-shaped spermathecal diverticula and separate openings into oesophagus, five species ( $F$. strenua Rota, 1995; $F$. aurita Issel, 1905; F. auritoides Schmelz, 2003; F. 
longiducta Dózsa-Farkas, 2015; and F. phaeostriata Dózsa-Farkas, 2015) are similar to the new species (Issel 1905, Schmelz 2003, Rota 1995, Dózsa-Farkas et al. 2015). The main differences that distinguish the new species from all the above-mentioned ones are the blood colour (in the new species light pink, in the others colourless) and the very large spermathecal ectal glands. Another species, F. magna Friend, 1899, has red blood and similar spermathaecae with two large ectal glands. However, F. zicsii sp. nov. can be easily distinguished from $F$. magna by the following characters: 1$)$ smaller size $(14-20 \mathrm{~mm}$ long and 48-64 segments vs. $30-50 \mathrm{~mm}$ and $70-$ 96 segments); 2) more chaetae: mostly $4-5$ in preclitellar bundles both ventrally and laterally $(2$ or 3 , only very rarely 4 in $F$. magna); 3) oesophageal appendages type b (type c in F. magna); 4) coelomo-mucocytes with a characteristic texture, the nucleoli are not visible (nucleoli conspicuous in $F$. magna); 5) seminal vesicle large (in $F$. magna absent). For descriptions of $F$. magna see Friend (1899) and Schmelz (2003).

\section{Results of molecular analysis}

Results of molecular analyses are shown in Fig. 6. In total, 16, 14 and 16 sequences were determined from various Fridericia specimens in the case of ITS, $\mathrm{CO} 1$ and $\mathrm{H} 3$, respectively. In addition to two $F$. zicsii sp. nov. individuals, specimens of five other, morphologically similar species $(F$. phaeostriata, $F$. longiducta, $F$. connatiformis, $F$. bisetosa and $F$. connata, all collected from woodland habitats in Hungary; Appendix 3) were also sequenced. The results of molecular analyses confirmed our morphological results, since the sequences of the three studied taxonomic markers for $F$. zicsii sp. nov. were clearly separated from those of all similar Fridericia species.

\section{DISCUSSION}

The enchytraeid fauna (47 species of 14 genera) of this area is quite diverse, and consists mostly of species typical to the Hungarian or wider

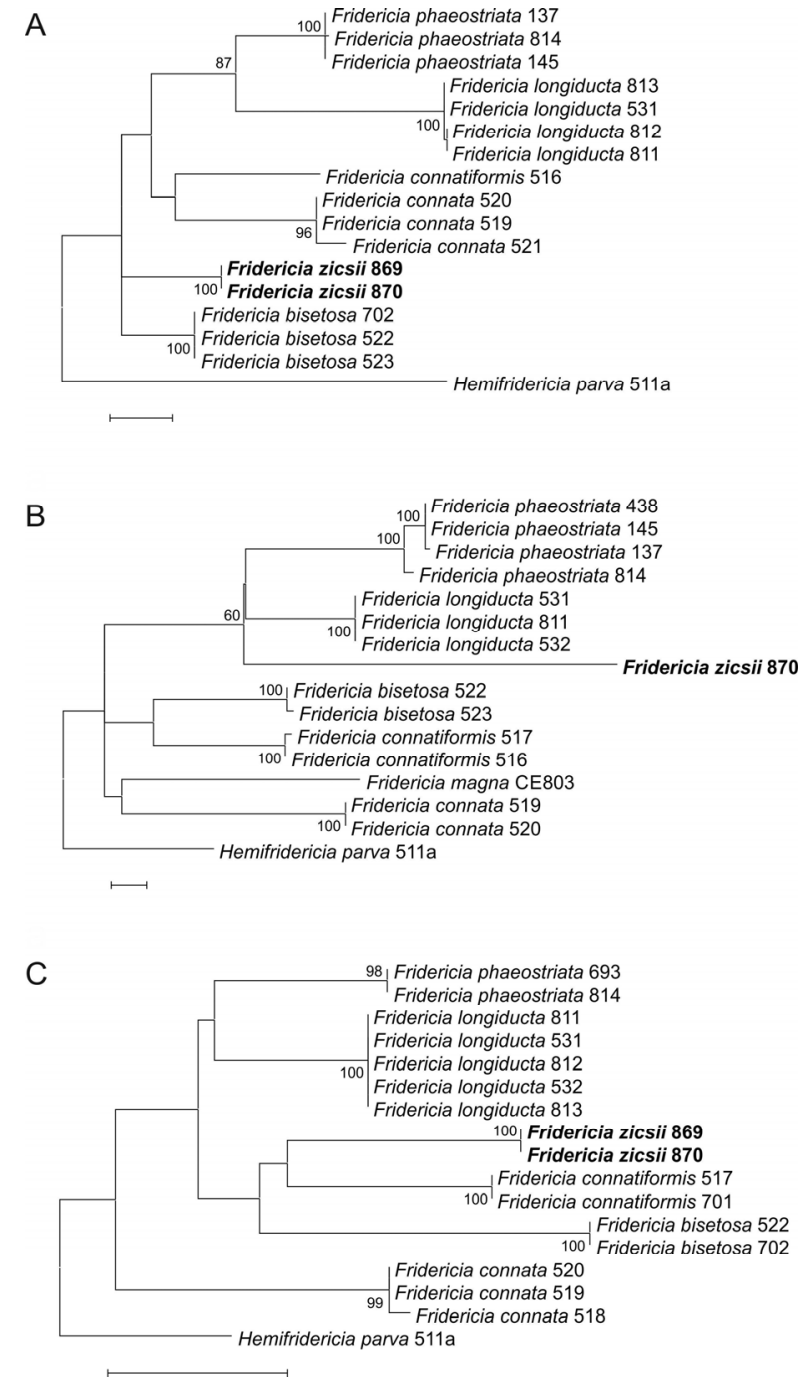

Figure 6. Maximum likelihood (ML) phylogenetic trees of selected Fridericia species based on the ITS region (A), CO1 (B) and $\mathrm{H} 3$ genes (C). Bootstrap values greater than 50 are shown at the nodes. Sequences from the new species described here appear in bold. A $=$ ML tree of the ITS region based on 425 nucleotide positions using the $\mathrm{K} 2+\mathrm{G}$ nucleotide substitution model. $\mathrm{B}=\mathrm{ML}$ tree of the $\mathrm{CO} 1$ gene based on 405 nucleotide positions using the TN93+G+I substitution model. $\mathrm{C}=$ ML tree of the $\mathrm{H} 3$ gene based on 175 nucleotide positions using the $\mathrm{K} 2+\mathrm{G}$ substitution model. Scale bars $=$ 0.05 substitutions per nucleotide position. Sequences from the new species are highlighted with bold letters.

Central European fauna (Schmelz \& Collado 2010). In terms of species numbers recorded in the investigated sites, the hay meadow of Gödörházi rétek (site 5 in Appendix 1) showed with 32 species the highest value. The species compo- 
sition of this site reflects best the mountain or subalpine character of the area. Moreover only here (and at the neighbouring site 4, the edge of an alder carr), specimens of $F$. zicsii sp. nov. were found. This new species was clearly distinguishable from other Fridericia species based on morphological characters and molecular taxonomical analyses.

Of all other studied Hungarian mountain ranges, the fauna of Örség NP is most similar to the fauna of Zemplén Mts. (Dózsa-Farkas 2007). Mesenchytraeus armatus, Mesenchytraeus glandulosus and Marionina simillima are North European or subalpine fauna elements. Comparing the two Sphagnum mires studied here (sites 8 and 9a) with the four other Sphagnum mires in the northeastern part of Hungary investigated earlier (Dózsa-Farkas 1990, 1991), it is worth noting that the enchytraeid fauna of the mire in Farkasfa (site 8) was poor in species (4 species) while the mire in Szöce (site 9) with its 20 recorded species widely differed from these. Interestingly, this species-rich sampling site was located in the middle of the mire (site 9a), while at its edge (sites 9b and c) only seven species were recorded. We expected an opposite trend. The reason for this can be the higher $\mathrm{pH}$ value measured (6.8-6.9) in the mire in Szöce, the site was not as nutrient-poor as in case of the other mires (Pócs et al. 1958) and furthermore, besides Sphagnum spp. other moss species were also present.

Chamaedrilus (=Cognettia) chalupskyi is a new species for the Hungarian fauna. It should be noted that almost all Cognettia species were recently revised and relegated to the genus Chamaedrilus Friend, 1913 (Martinsson et al. 2015), but this nomenclatural act was questioned and a case has been submitted to the International Commission on Zoological Nomenclature (Schmelz et al. 2015), therefore both genus names appear throughout this article.

Acknowledgements - Our thanks are due to Dr. János Farkas and Dr. Zoltán Tóth for their assistance in sampling. This research was financed by the Hungarian Scientific Research Fund (OTKA K77999). Tamás Felföldi was supported by the János Bolyai Research Scholarship of the Hungarian Academy of Sciences.

\section{REFERENCES}

CECH, G. \& DÓZSA-FARKAS, K. (2005): Identification of Fridericia schmelzi sp. n. combining morphological characters and PCR-RFLP analysis. In. POP, V., PoP, A. (Eds.) Advances in Earthworm Taxonomy II (Annelida: Oligochaeta). Cluj University Press. p. 99-118.

Colgan, D.J., Mclauchlan, A.A., Wilson, G.D.F., LiVInGSTON, S.P., EDGECOMBE, G.D., MACARANAS, J., CASSIS, G. \& GRAY, M.R. (1998): Histone H3 and U2 snRNA DNA sequences and arthropod molecular evolution. Australian Journal of Zoology, 46: 419-437. doi: 10.1071/ZO98048

DÓZSA-FARKAS, K. (1990): New Enchytraeid species from Sphagnum-bogs in Hungary (Oligochaeta: Enchytraeidae). Acta Zoologica Academiae Scientiarum Hungaricae, 36 (3-4): 265-274.

DÓZSA-FARKAS, K. (1991): The enchytraeid fauna (Oligochaeta: Enchytraedae) of Sphagnum-bogs in Hungary. Állattani Közlemények, 77: 17-23. [In Hungarian]

DÓZSA-FARKAS, K. (2002): The enchytraeid-fauna (Oligochaeta: Enchytraeidae) of the Fertö-Hanság National Park. In. MAHUnKA, S. (Ed.) The Fauna of the Fertö-Hanság National Park I. Hungarian Natural History Museum, Budapest, p. 151-163.

DÓZSA-FARKAS, K. (2005): Fridericia eiseni sp. n., a new enchytraeid species close to the Fridericia ratzeli (Eisen, 1872). Proceeding of the Estonian Academy of Sciences Biology, Ecology, 54 (4): 279-291.

DÓZSA-FARKAS, K. (2007): Comparative enchytraeid faunistic investigation of the northeastern mountain range in Hungary. In. TAJOVSKY, K., SCHLAGHAMERSKY, J. \& PIZL, V. (Eds.) Contributions to Soil Zoology in Central Europe II. Proceedings of the 8th Central European Workshop on Soil Zoology, Ceske Budejovice, Czech Republic April 20-22, 2005. p. 29-35.

DÓZSA-FARKAS, K. (2013): New Fridericia species (Oligochaeta: Enchytraeidae) from Vértes Mountains of Hungary. Acta Zoologica Academiae Scientiarum Hungaricae, 59 (4): 401-421.

DÓzSA-FARKAS, K. \& CECH, G. (2006): Description of a new Fridericia species (Oligochaeta: Enchytraeidae) and its molecular comparison with two morphologically similar species by PCR-RFLP. Zootaxa, 1310: 53-68. 
DÓZSA-FARKAS, K. \& FELFÖLDI, T. (2015): Unexpected occurrence of Hemifridericia bivesiculata Christensen \& Dózsa-Farkas, 2006 in Hungary, a species presumed to be endemic to Devon Island, Canada, and its comparative analysis with $H$. parva Nielsen \& Christensen, 1959 (Enchytraeidae, Oligochaeta). Zootaxa, 3914 (2): 185-194. doi: 10.11646/zootaxa.3914.2.8

DÓZSA-FARKAS, K., ORTMANN-AJKAI, A. \& HORVÁTH, F. (2015): New enchytraeid species (Oligochaeta: Enchytraeidae) from the Danube-Dráva National Park. Acta Zoologica Academiae Scientiarum Hungaricae, 61(4): 305-327. doi: $10.17109 / A Z H .61 .4 .305 .2015$

DÖVÉNYI, Z. (2010): Magyarország kistájainak katasztere. [Cadastre of Hungarian regions]. MTA Földrajztudományi Kutatóintézet, Budapest, 876 pp.

Erséus, C., Rota, E., Matamoros, L. \& De Wit, P. (2010): Molecular phylogeny of Enchytraeidae (Annelida, Clitellata). Molecular Phylogenetics and Evolution, 57 (2): 849-858. doi: 10.1016/j.ympev.2010.07.005

FRIEND, H. (1899): New British annelids. Zoologist, 3: 262-265.

Graefe, U., DÓzsA-FARKAS, K AND Christensen, B. (2005): Achaeta unibulba sp. n. A widespread European species (Oligochaeta, Enchytraeidae). Proceedings of the Estonian Academy of Sciences Biology, Ecology, 54 (4): 271-278.

GYÖNGYÖSSY, P. (2008): Gyántásország. Történeti adatok az örségi erdö természetvédelmi értékeléséhez [Historical Data for the Forestry and Conservational Evaluation of the Forests in Örség Region]. Kerekerdő Alapítvány, Szombathely., 110 pp.

FOLMER, O., BlACK, M., HOEH, W., LUTZ, R. \& VRIJENHOEK, R. (1994): DNA primers for amplifycation of mitochondrial cytochrome $\mathrm{c}$ oxidase subunit I from diverse metazoan invertebrates. Molecular Marine Biology and Biotechnology, 3: 294-299.

ISSEL, R. (1905): Oligocheti inferiori della fauna italica. Zoologische Jahrbücher. Abteilung für Anatomie, 22: 451-476.

JuhÁsz, P., Bidló, A., HeIl, B., KovÁcs, G., ÓdOR, P. (2011): Örségi erdőtalajok széntartalmi vizsgálata (Investigation of carbon content of forest soils in
Örség, West Hungary). Talajvédelem, (suppl.): 377-382.

KANE, R.A. \& Rollinson, D. (1994): Repetitive sequences in the ribosomal DNA internal transcribed spacer of Schistosoma haematobium, Schistosoma intercalatum and Schistosoma mattheii. Molecular and Biochemical Parasitology, 63: 153156. doi: 10.1016/0166-6851(94)90018-3

Martinsson, S., Rota, E. \& ERsÉUS, C. (2015): Revision of Cognettia (Clitellata, Enchytraeidae): reestablishment of Chamaedrilus and description of cryptic species in the sphagnetorum complex. Systematics and Biodiversity, 13 (3): 257-277. doi: $\underline{10.1080 / 14772000.2014 .986555}$

O'CONNOR, F.B. (1962): The extraction of Enchytraeidae from soil. In. MURPHY, P,W. (Ed.) Progress in Soil Zoology, Butterworths Publishers, London, p. 279-285.

Pócs, T., Domokos-NAGy, É., PÓcs-Gelencsér, I. \& VIDA, G. (1958): Vegetátionsstudien im Örség (Ungarisches Ostalpenvorland). In. ZÓLYOMI, B (Ed.) Die Vegetation ungarischer Landschaften 2, Academiai Kiadó, Budapest, 124 pp.

RotA, E. (1995): Italian Enchytraeidae (Oligochaeta). I. Bollettino di Zoologia, 62: 183-231. doi: $\underline{10.1080 / 11250009509356067}$

SCHMELZ, R.M. (2003): Taxonomy of Fridericia (Oligochaeta, Enchytraeidae). Revision of species with morphological and biochemical methods. $A b$ handlungen des Naturwissenschaftlichen Vereins in Hamburg (Neue Folge), 38: 1-415.

SchMElZ, R.M., Collado, R. \& RÖMBKE, J. (2015): Case 3689: Cognettia Nielsen \& Christensen, 1959 (Annelida, Oligochaeta, ENCHYTRAEIDAE): proposed precedence over Euenchytraeus Bretscher, 1906 and Chamaedrilus Friend, 1913. Bulletin of Zoological Nomenclature, 72: 186-192.

Tamura, K., Stecher, G., Peterson, D., Filipski, A. \& KUMAR, S. (2013): MEGA6: Molecular Evolutionary Genetics Analysis version 6.0. Molecular Biology and Evolution, 30: 2725-2729. doi: $10.1093 / \mathrm{molbev} / \mathrm{mst} 197$

TímÁr, G., ÓdOR, P., BodOnCZI, L. (2002): The characteristics of forest vegetation of the Örség Landscape Protected Area. Kanitzia, 10: 109-136. 